WEJ, Vol 2 No 2 September 2018

\title{
THE EVALUATION OF NATIONAL EXAMINATION OF ENGLISH SUBJECT AT SECONDARY SCHOOL
}

\author{
Indra Yoga Prawiro \\ S1 - English Education Department \\ Wiralodra University - Indramayu \\ indrayoga@unwir.ac.id
}

\begin{abstract}
The implementation of National Examination in Indonesia always becomes an interesting discussion both in education field and social life. One of the debates in the implementation of National Examination is about the fairness, many experts stated that the implementation of National Examination is unfair because the threeday exam is used to determine the success or failure of a student's three years of high school. The second issue is about the quality of education in Indonesia's school is gravely uneven. Some schools have luxury facilities and infrastructure, while others barely have a school building. So, to apply and expect the same standard from all of them is harsh and unrealistic. This study would like to analyze the questions in National Examination. The writer takes English test for science students as the primary data to answer the questions. The writer focuses on the principle of language assessment implemented in construction of English test in National Examination and the appropriateness of English test questions in National Examination based on the standardize of language assessment. The result shows that National examination in this case English test has been designed accordance to the principle of assessment. For standardized test of national examination, there are some types of test items are hardly to be found in the test. In terms of reading test items, multiple choices which are indicating to find reference words, phrase or sentence are not given in English test. It is dominated by finding out the detail or specific information about the text, implicit and general description about the text. Overall the English test in national examination has been design according to the standardized test. Only for several things need to be improved in term of test items variety in reading skill.
\end{abstract}

\section{Keywords : National Exam Evaluation, English Subject, Secondary School.}

\section{INTRODUCTION}

The implementation of National Examination in Indonesia always becomes an interesting discussion both in education field and social life. One of the debates in the implementation of National Examination is about the fairness, many experts stated that the implementation of National Examination is unfair because the threeday exam is used as the sole assessment to determine the success or failure of a student's three years of high school. The second issue is about the quality of 
education in Indonesia's school is gravely uneven. Some schools have luxury facilities and infrastructure, while others barely have a school building. So, to apply and expect the same standard from all of them is harsh and unrealistic. This condition will open any effect for the students as the effort to pass the exams. The first problem prompts students to act dishonestly, while the second problem will force schools to allow and even encourage cheating to take place.

For Indonesian Government the National Examination has the biggest role in order to measure the successful of National Education System. It also can be used as a standard evaluation system of primary and secondary school and the equation of quality of education level among the areas. However every year, the government tries to improve the standard of the test and to achieve those goals the test forms of every subject in National examination should be met to the national standardized test. Browns (2004:67) stated that the standardized test presupposes certain standard objectives, or criteria that are held constant across one form of the test to another. He also stated that a good standardized test is the product of a thorough process of empirical research and development. It dictates standard procedures for administration and scoring. And finally, it is typical of a norm referenced test, the goal of which is to place test-takers on a continuum across a range of scores and to differentiate test-takers by their relative ranking.

\section{LITERATURE REVIEW}

Oakes and Lipton (2007) explain that standardized tests are claimed to be objective, valid, and reliable. It is objective because it is not open to bias and interpretation, and the performances can be simplified by statistical figures. Also, all test-takers are perceived to have an equal and fair opportunity to demonstrate their ability. It is valid because the information collected and analyzed is perceived to be trustworthy. Finally, it is reliable because the results are trusted to be consistent. Since the purpose will be general for all kinds of students with their learning types.

Moreover, the standardized test has advantages and disadvantages; Brown in Language Assessment (2004:68) explained the advantages and disadvantages. The advantages of standardized test are it is ready made previously validated product. This condition frees the teacher from having to spend hours creating a test administration to large groups. Scoring procedures are streamlined. Standardized tests also designed to have face validity. The disadvantages of standardized tests are the use of overall proficiency test as an achievement test simply because of the convenience of the standardization. It also opens potential misunderstanding of the difference between direct and indirect testing. Some standardized tests include tasks that do not directly specify performance in the target objective.

Some experts delivered some critiques toward standardized testing which have been commonly ignored by the policy makers. For example, Oakes and Lipton (2007), they argue that there are three major flaws of standardized testing. First, it still uses the assumptions of learning theories from the nineteenth-century behavioral psychology, and does not reflect the rapidly emerging views from the cognitive and educational psychology. For instance, it is assumed that learning happens when 
teacher breaks down the knowledge into small bits of information, which is transmitted by the teacher to the learners. Second, it inherits the flaws of the logic and technology of IQ tests. For instance, the presumption of "bell curve", where test are designed to produce a wide range of scores, with most of the test-takers score in the average range, and only few can reach the high scores. Third, it is culturally bias. Different cultures have different areas of strengths that are emphasized. Some value memorization, some value personal and social responsibility. Also poverty and oppressive social conditions may influence the test-takers in the standardized test.

When a standardized test is used as the tool to determine students' academic future, it can be considered as high-stakes testing. Janesick (2001:112) explains that the term 'high-stakes testing' refers to the test "for which the consequences of a student's score are extremely serious". Janesick argues that the high-stakes testing would harm low-income and minority students because funding would be taken away from the poor-scoring schools. Moreover, listing schools as failing schools based on the high-stakes testing results would give an impact to the students, who might consider themselves as failing students as well.

This condition leads the government in case of designing the test in which it is appropriate for them. Brown (2004:19) explained there are some principles have to be considered in assessing language,

1. Practicality, it can be explained that as a test should not be excessively expensive, it also should stay within appropriate time constraints, then it also should be relatively easy to administer and the last it should have specific and time-efficient scoring/evaluation procedure.

2. Reliability, it can be described that the test should be consistent and dependable.

3. Validity, it can be concluded that the extent to which inferences made from assessment results are appropriate, meaningful and useful.

4. Authenticity, it explains the test in case of the degree of correspondence of the characteristics of a given language test task to the features of a target language task.

5. Washback that is the test in case of the effect of testing on teaching and learning.

Brown (2004:69) also explained that the standardized tests of language also should meet the criteria of standardized tests, they are:

1. Determine the purpose and objectives of the test,

2. Design test specification,

3. Design, select and arrange test task/ items,

4. Make appropriate evaluation of different kinds of items,

5. Specify scoring procedures and reporting formats. Thus criteria should be accomplished in the test items, then it is called as standardized tests.

\section{Research Question}

The National Examination has been subject of controversy since its inception. It becomes notorious for answer key leakage, cheating, fraud and corruption. Included the quality of test based on principle and standardization of language assessment. In 2014 the Indonesia education ministry recorded a graduation rate $99.52 \%$ for all high schools in Indonesia (Litbang.Kemdikbud.go.id). It shows that 
more than $7.811(0,48 \%)$ of students cannot pass the National Examination. That is why in this study, the writer would like to analyze the questions in National Examination Academic Year 2014. The writer takes English test for science students (The sample of test is attached) as the primary data to answer the questions. The writer will use the theory of Brown (2004) to measure the principle and standardization of National Examination Test of English. The problem described above will be formulated into the following questions of this study, they are:

1. How is the principle of language assessment implemented in construction of English test in National Examination?

2. Does English test in National Examination appropriate based on the standardize of language assessment?

\section{FINDING AND DISCUSSION}

After reading some resources and analyze the English Test in National Examination, these are the discussion relates to the some principles of language assessment in the implementation of National Examination in 2014.

A. Practicality. Some points of practicality are:

$>$ The test is not expensive; the test given in National Examination is free of charge. As a part of Government program, The National Examination has been managed and paid by Government.

> Stays within appropriate time constrain, the students are given enough time in doing English test, in 2014, it is held on April 16th 2014. The schedule has been announced before that time. The test of English is about two hours. It is started at 7.30 a.m and finished at 9.30 a.m.

$>$ It is relatively easy to administer, the government has given the information about all of equipments to support English test such as the tape recorder, CD and etc. Then it should be checked a day before English test is held for tape recorder and for $\mathrm{CD}$ the school can check 30 minutes before. The government also provided additional $\mathrm{CD}$ that can be used if the first $\mathrm{CD}$ cannot be played.

$>$ It has a scoring or evaluation procedure that is specific and time-efficient, all the answer sheets are sent to the committee in every single province, the procedure in scoring has been determined and the students have the responsibility only to answer the questions and the teacher only supervise the class. For the result it will be checked by computer system.

B. Reliability. Is about consistent and dependable of the test

- Student-related reliability, the National Examination is held about 3 days from 14 April to 16 April 2014 and the schedule for English test is on third day. English is put in the first schedule or in the morning, it means that the students are in fresh condition, with expectation that this condition will support the students to be more concentrate in answering the question.

Rater-reliability, it is computer-based system that checks the result so there is no doubt for the rater-reliability. The possibility of error comes from the students who are not filling the circle correctly or unintentionally ripped the 
paper. To prevent that problems the supervisors always check and remind the students to keep the answer sheet neatly.

$>$ Test administration reliability, some problems in National Examination 2014 such as the availability of copy papers. Some schools in several areas cannot held the National Examination in similar time because there is no copy of paper (www.tempo.co.id 14 April 2014 and www.repubblika.co.id 12 April 2014).

$>$ Test reliability, the total of the English test has been measure according to the ability of the students, the time also has been adjusted by the prediction the students' ability. The range of test items difficulty also has been adjusted properly.

C. Validity. Is about appropriateness, meaningful, and useful of the test

$>$ Content - related evidence, the content of English test in the National Examination listening and reading. There is only one number of writing skills used to measure the students, that is in number 42 (rearrange the sentences).

$>$ Criterion - related evidence, language proficiency is included in English test in National Examination

$>$ Consequential validity, because of there is any gap between some students in some schools, so the enrichment program before the test was held. So the students can get similar information (prediction) before answering the questions.

$>$ Face validity, the tests are design in familiar form for the students. In the National Examination especially for English subject, the government chooses multiple choices to measure students language skill.

D. Authenticity. It should be enacted in real life, the material in the test is given which connect then to real world. Such as the text about "KAKA" for the students, Kaka is one of the famous football players in the world. His carrier in AC Milan and Real Madrid makes him known by many people in the world including Indonesian students. The other text entitled "Butterfly" and "Octopus" are also known by the students.

E. Washback. It is about the effect of testing in teaching and learning. Washback of National Examination is the teacher prepare better in teaching and learning for the students so that they will be ready for the next examination.

To answer the second question, Brown also gives guidance in designing standardized test, they are

1. Determine the purpose and objectives of the test

The government sets the indicators of the English test for National examination as the purpose and objectives of the test, in which it covers all material that have been given to the students in senior high school for any kinds of programs. 
Table 1.1 indicators checklist

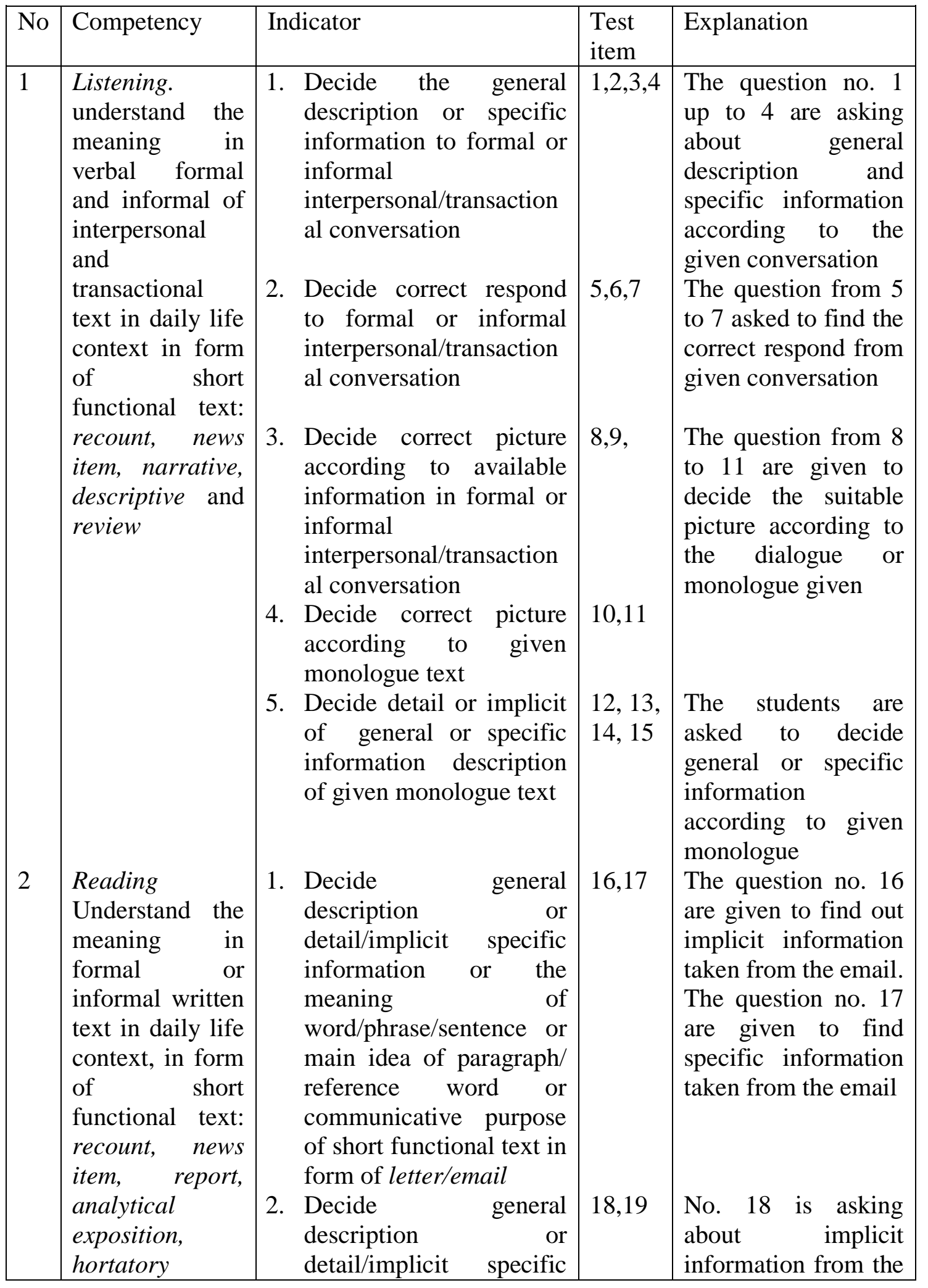




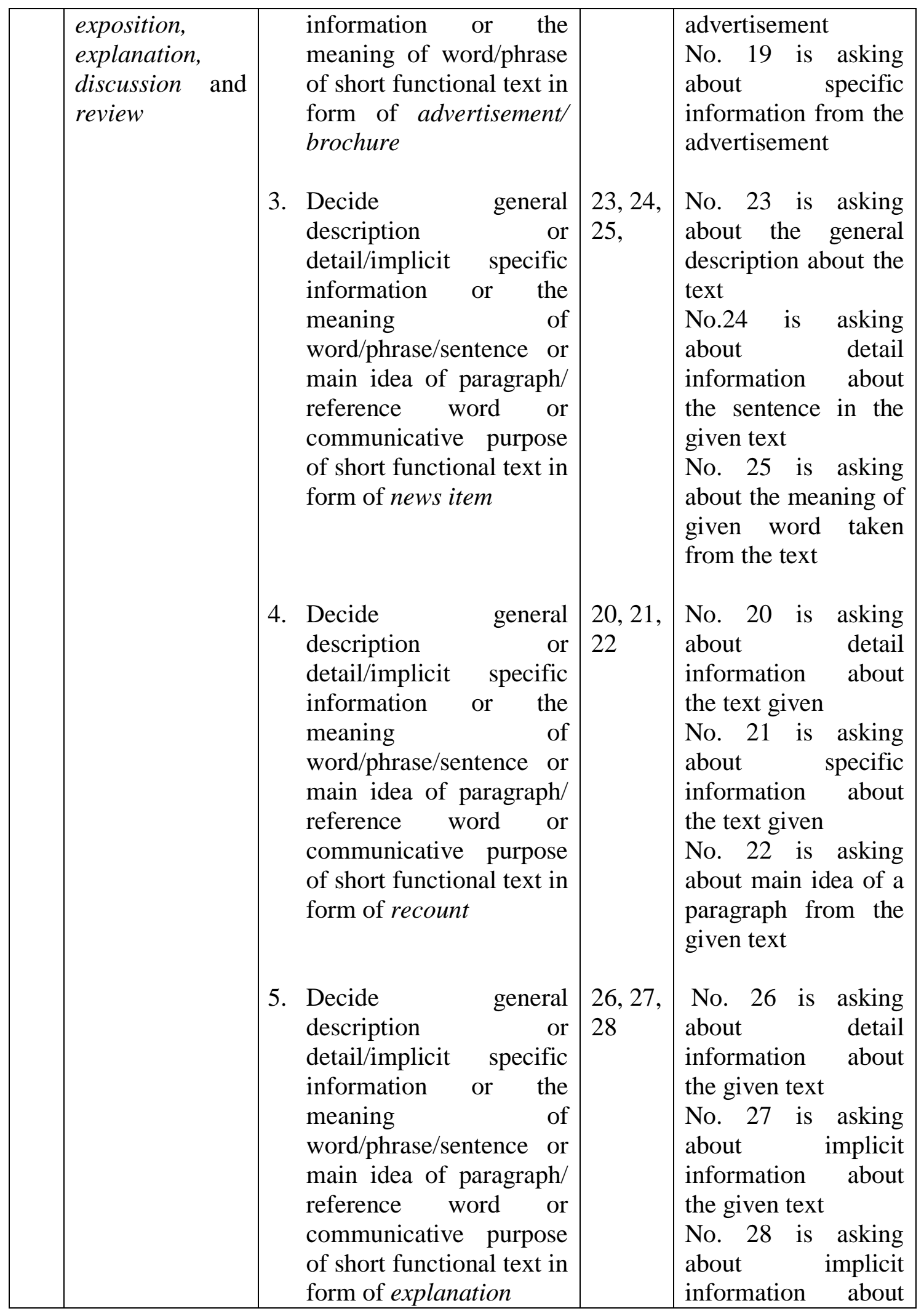




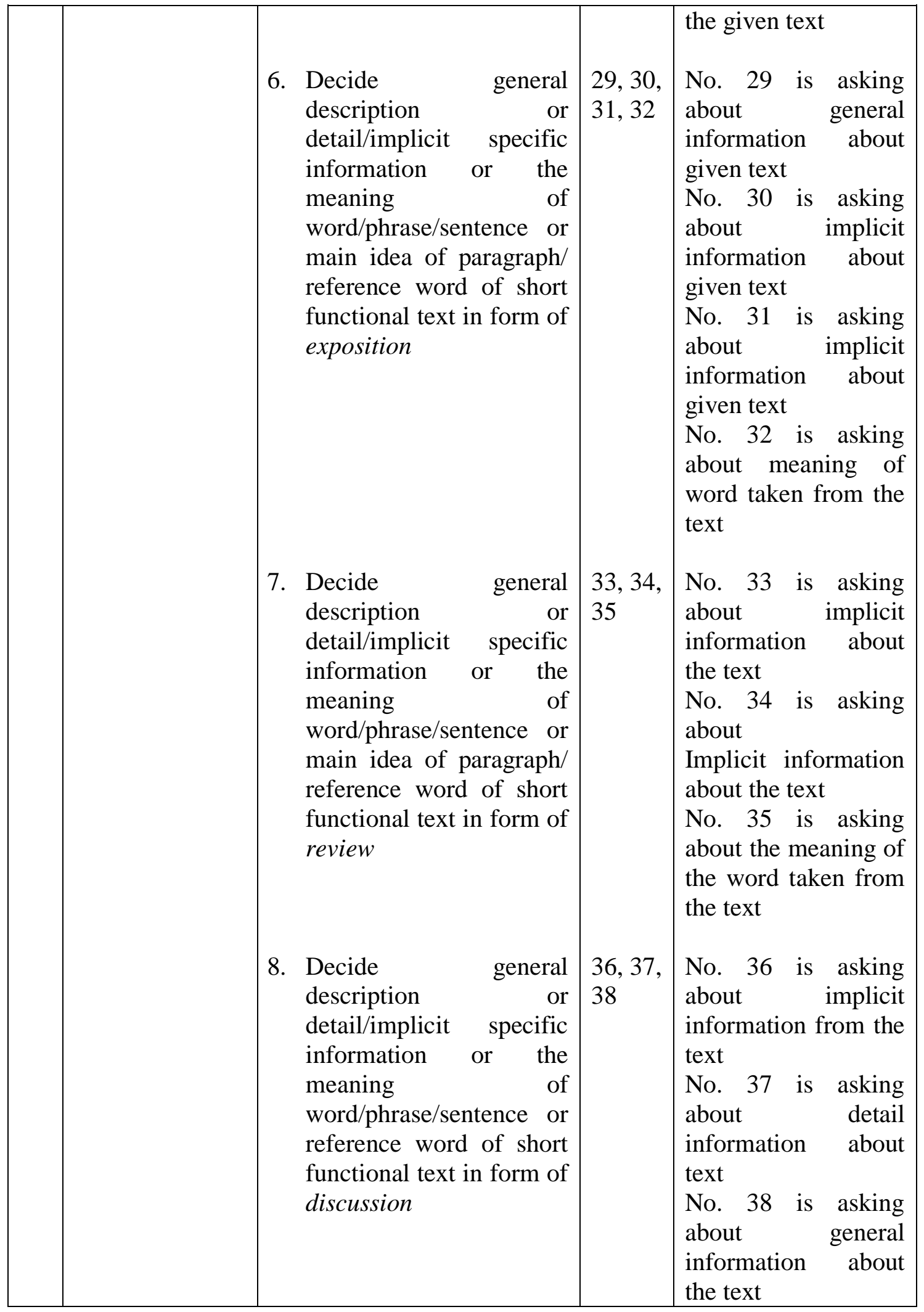


WEJ, Vol 2 No 2 September 2018

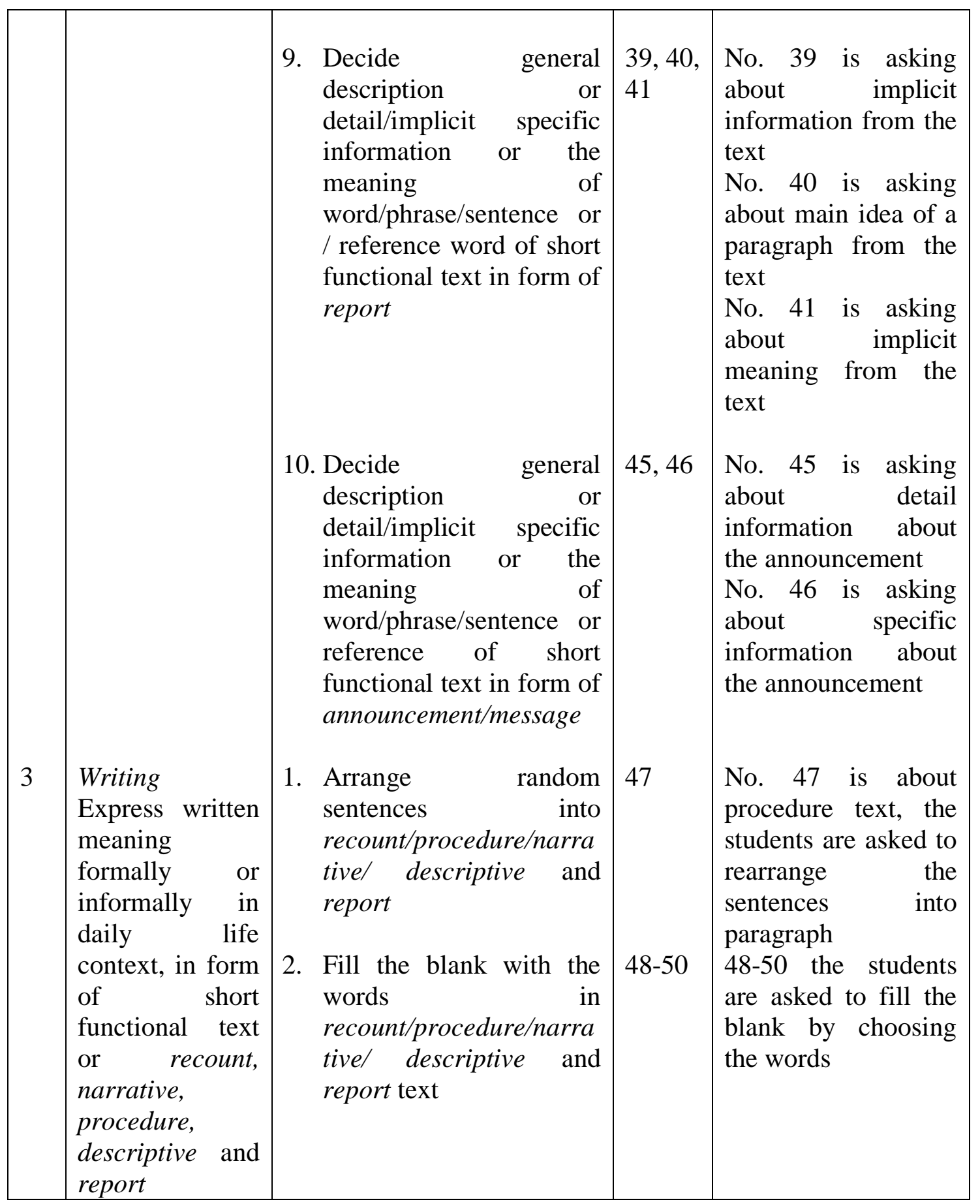

2. Test specification

English test specifications in national examination are listening, reading and writing skills. Those specifications have been determined by the government. For speaking skill, it is performed in practice session. All language skills are performed in National examination. 
3. Select, and arrange test tasks/items

The items in English tests also listed clearly in the indicators of national examination.

4. Appropriate evaluations of different kinds of items

The evaluations of the test items are applied in case of the discussion in evaluating the national examination.

5. Scoring procedures and reporting formats

Scoring procedures and reporting formats also have been provided by the government.

6. Perform ongoing construct validation studies

The validation studies are open for National Examination includes English test in national examination. This is done in order to get betterment of National examination especially for English test.

\section{CONCLUSION}

According to the finding and discussion above, the English test has met the principle in assessing language performance/ test. National examination in this case English test, the design has been accordance to the principle of assessment. For standardized test of national examination, there are some types of test items are hardly to be found in the test. In terms of reading test items, multiple choices which are indicating to find reference words, phrase or sentence are not given in English test. It is dominated by finding out the detail or specific information about the text, implicit and general description about the text. Overall the English test in national examination has been design according to the standardized test. Only for several things need to be improved in term of test items variety in reading skill.

\section{REFERENCE}

Aprianto, K. (2013). Validity and washback of English test in National Examination. English Education Journal , 7.

Apriliani, A. (2013). Item Analysis of English Tryout test. Muria Kudus University Journal , 15.

Brown, H. D. (2004). Language Assessment principles and classroom practice. Sanfransisco: Longman.

Janesick, V. J. (2001). The assessment debate: A reference handbook. Santa Barbara, CA: ABC- CLIO. 
WEJ, Vol 2 No 2 September 2018

Kemdikbud. (2014). Soal Ujian Nasional Bahasa Inggtis SMA Program Studi IPA. Indonesia.

Kemendikbud. (2014). Kompetensi Standar Isi Ujian Nasional SMP/SMA. Indonesia.

Oakes, J., \& Lipton, M. (2007). Teaching to change the world (3rd ed.). Boston: McGraw-Hill.

Sulistiyo, G. H. (2009). English as a measurement test in the National Examination: Some Grassroots' voice. Teflin Journal , 24.

Syahril, I. (2007). Standardized testing in Indonesia Secondary Education: An Analysis on the impact of National Exit Exam (2005-2007). Colombia University Journal , 13. 